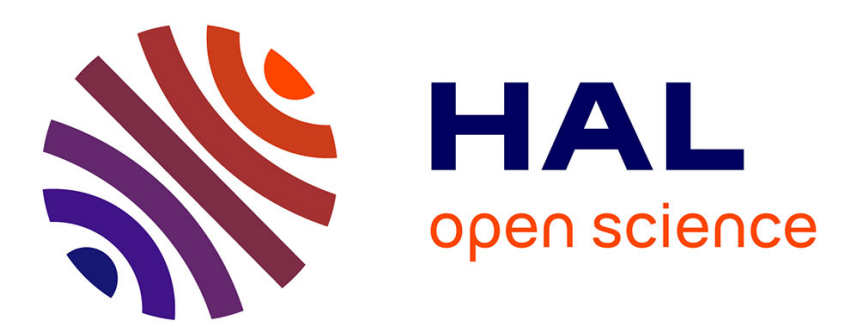

\title{
In Search of Entrepreneurs, Children and HIV/AIDS in Cameroon: A Marginalized Issue? \\ Larissa Kojoué
}

\section{To cite this version:}

Larissa Kojoué. In Search of Entrepreneurs, Children and HIV/AIDS in Cameroon: A Marginalized Issue?. Pranee Liamputtong (ed). Children, Young People and Living with HIV/AIDS: A CrossCultural Perspective, chapter 18, Springer Series, pp.309-319, 2015. inserm-01874790

\section{HAL Id: inserm-01874790 https://www.hal.inserm.fr/inserm-01874790}

Submitted on 14 Sep 2018

HAL is a multi-disciplinary open access archive for the deposit and dissemination of scientific research documents, whether they are published or not. The documents may come from teaching and research institutions in France or abroad, or from public or private research centers.
L'archive ouverte pluridisciplinaire HAL, est destinée au dépôt et à la diffusion de documents scientifiques de niveau recherche, publiés ou non, émanant des établissements d'enseignement et de recherche français ou étrangers, des laboratoires publics ou privés. 
Chapter 18

In search of entrepreneurs, Children and HIV/AIDS in Cameroon: A marginalized issue?

Larissa Kojoué, Ph D

Post doctoral fellow, University of Montreal/Research Associate Les Afriques dans le Monde (LAM)-Sciences Po Bordeaux

Larissa.kojoue@hotmail.fr 


\begin{abstract}
Since the early 2000s, the government of Cameroun has implemented three major initiatives directed at Orphans and Vulnerable Children due to HIV/AIDS (OVC). These are children whose survival, well being and development are being compromized by HIV and AIDS. The initiatives are namely; the bi multi-OVC program (2004-2008), the National Support Program for OVC (NSP-OVC 2006-2010), and the Children, HIV and AIDS program (2008-2012). Behind each of these initiatives stands a foreign and institutional operator (UNICEF, the French Cooperation, and the Global Fund). The implementation of these programs has been complex and quite far from the intended goals. Based on an in-depth analysis of Cameroonian policies for care and support to OVC, this chapter will show that despite the inclusion of this issue as a strategic priority in fighting against AIDS, Cameroonian authorities are non-significant managers. They much more accompany policies, instead of directing or driving. Public policies for OVC are therefore the result of international propositions rather than the consequences of formal and structured requests. They reflect the weakness and the deficiency of social movements against AIDS in Cameroon. They also expose the contradictions of global policies to fight against HIV/AIDS, which tend to neglect and conceal the social, economic, sanitary and family dynamics that affect children daily.
\end{abstract}

Keywords: HIV/AIDS, OVC, Policies, entrepreneurs, Global Health, Cameroon 


\section{Table of Contents:}

1. Introduction

2. Agenda-setting as an indicator of power relations

3. Children and HIV/AIDS in Cameroon: Agenda setting-conditions

4. A plural marginality fuelled by the weakness of local stakeholders and political context

4.1 An assisting role and not an entrepreneur's role: About Cameroonian associations supporting OVC

4.2 A political environment not particularly favourable to public policies entrepreneurship

5. Conclusion 


\section{Introduction}

The objectives of the fight against HIV/AIDS can only be reached if the reduction of inequalities with regard to the epidemic is taken into consideration (Piot, 2010). Among the populations most vulnerable to the epidemic and its consequences, are children under the age of $15.90 \%$ of the children most affected by HIV/IADS are found in Africa (UNAIDS, 2013). This significantly undermines social and economic development of countries, which are permanently affected (UNAIDS et al. 2004; UNICEF, 2006, 2013). Cameroon is one of the countries where $90 \%$ of people live with limited or no access to antiretroviral treatment (ONUSIDA, 2013). While children represent about $10 \%$ of the 550000 people living with HIV (PLWHIV), pediatric antiretroviral treatment coverage represents less than 5\%. The mother-to-child transmission of HIV (MTCT) is still the main mode of infection for persons under the age of 15. Besides fighting against AIDS programs, only $2 \%$ of public expenditure in 2012 is devoted to Orphans and other children made vulnerable by AIDS (OVC or HIV/AIDS-infected/affected children) (GTC-CNLS, 2012). In the context of generalized epidemics where HIV prevalence is $4.3 \%$, the real importance given to children in HIV/AIDS public policies is of concern. Other related questions include: who are the stakeholders involved in the management of medical and what are the social consequences of children getting infected? What are the terms of their interventions? Can we attribute the lack of visibility of this issue to the weakness of local actors or unfavourable global economic conditions?

Based on actions carried out for children less than 15 years confronting HIV/AIDS, this chapter examines social mobilization and its impact on care and support for HIV/AIDS infected and affected children in Cameroon. A study of the context that led to the inclusion of this issue on the national agenda, as well as measures implemented since early 2000s, suggest that besides the weakness of local public policies entrepreneurs and their intervention capacities, care to children confronting HIV/AIDS raises issues that go beyond medical and social aspects which concern the social determinants of health, wellbeing and protection of all children. 


\section{Agenda Setting as an Indicator of Power Relations}

Putting a question on agenda is one of the fundamental steps of public action. It refers to the process by which a problem is set to be examined by the State. It is important to identify why the State is particularly interested in certain problems at a given moment rather than others. According to available literature, agenda setting is the result of a dynamic and interactive process (Cobb \& Elder, 1972; Kingdon, 1984; Stone, 1989; Garraud, 1990; Hassenteufel, 2010). This process takes into account several factors. Some factors are related to the capacity of stakeholders (politicians, experts, social groups, and so on) to have their problem considered by public authorities. These are public policies entrepreneurs (Kingdon 1984), moral entrepreneurs (Becker 1985) or committed entrepreneurs (Cobb \& Elder 1972). Other factors are related to the inherent characteristics or intrinsic properties of the problem (incidence, severity, scope), or more precisely how it is presented (a crisis, a scandal, an affair). Some structural and circumstantial factors related to the political context (change of government) and economic (budget) are also factors influencing agenda setting.

According to Jacques Lagroye (2003, 2006), the emergence of a problem in the public arena is the result of a process of collective mobilization and action. All problems do not have the same ability to access the public and the State, and this ability depends on factors more often related to the characteristics of stakeholders involved in these moments than on the problems themselves. Moreover, despite the severity of the HIV epidemic in sub-Saharan Africa and despite knowledge on its dramatic consequences on the health, the well-being and the future of children, I argue that the idea of taking care of children under 15 years (in ways programs have been defined) was not self-imposed in the Cameroonian political agenda. I will show that it is precisely the combined action of some actors that led to various support programs (that we shall develop in the next section). In the same vein, the low interest for this problem at the operational level is indicative of the weakness of the actors involved in the definition of public policies 
relating to AIDS in Cameroon. This weakness in actors contrasts with the image of the entrepreneur developed by political sociology.

Although the contexts and stakeholders to which the concepts of entrepreneurs have been applied vary, the dominant approach in political sociology assigns to the entrepreneur, a disruptive and transformative role, and even a modifier of social order (Eisenstadt, 1980; Fligstein, 2001; Lagroye, 2003a Hassenteufel, 2010; Bergeron et al., 2011). Public policies entrepreneurs are indeed stakeholders who have the ability to influence and control public action, from its definition to its implementation. These actors play an active role in providing guidelines to a problem, and thereby showing how to solve it (Muller, 2000). Entrepreneurs of public policies or committed entrepreneurs differ from other social actors in their leadership abilities, their desire to satisfy their interests by transforming the existing orders rather than reproducing them (Bergeron et al., 2011).

In the Cameroonian context, this theoretical framework raises several issues: Could nonState actors in the fight against AIDS be described as entrepreneurs or leaders? How are they involved in the development and implementation of AIDS public policies? Do they have the opportunity and the capacity to intervene in State action? With agenda setting analysis, it will be possible to see what importance is given to children's health and social care in HIV/AIDS policies; and also, what are the conditions for a sustainable continuation of this problem among government's priorities.

\section{Children and HIV/AIDS in Cameroon (OVC): Agenda Setting Conditions and} Challenges

The term OVC, for orphans and other vulnerable children due to HIV/AIDS, appeared in the early 2000s (Hunter \& Williamson, 2000). While until the late 1990s, the predominant picture of the impact of HIV on children were AIDS orphans, taking into account the vulnerability criterion will lead to the institutionalization of the orphans and other vulnerable children due to HIV/AIDS category. This term refers to all children who in one way or the other suffer the consequences of the epidemic: children living with HIV, children exposed to HIV, children living in households affected by AIDS, children 
who lost one or both parent due to AIDS, and so on. The argument that guides this classification is that OVC are more exposed than their peers to some problems: education, healthcare, nutrition, loneliness, and so forth. Medical criterion goes along with social and psychological criterion (UNICEF 2006). Despite the ambivalence in this category being criticized for the non-operational nature of the concept of vulnerability under $\operatorname{AIDS}^{1}$ (Singhal et al., 2003; Skinner et al., 2004; Gillespie et al., 2005; Williamson 2008), governments of countries most affected by AIDS are invited to take measures targeting OVC in their national response. This chapter is based on three national programs of care and support to OVC.

Program 1: The first government program to support OVC was introduced in Cameroon in 2004. This was a pilot program jointly supported by UNICEF, the French Cooperation and the Ministry of Social Affairs (Minas). It is the bi-multi OVC program (bilateral and multilateral cooperation) covering a period of 36 months. The program included provision of social, nutritional, medical and academic support to 10,000 children identified as AIDS OVC. Initially limited to three pilot sites (three urban councils of medium density), this project will then be scaled-up nationwide.

Program 2: Due to substantial funding from the Global Fund, Cameroon government will develop a National Support Program for OVC (NSP-OVC) modeled on the bi-multi project. For an initial term of five years (2006-2010), NSP-OVC is the first national program of social pediatrics for children under 18 years in Cameroon. 180,000 OVC will be identified as having special needs for support. The program's goal was to support $75 \%$ of the targeted children from 2006 to 2010. To implement this program, the government relied on about fifty local associations. Some of the associations were incompetent. One of the leaders of this program explained:

The first part of the program was a real mess (...). The Minas sent social workers in all partner associations of the program. Some of them had no office space to

\footnotetext{
${ }^{1}$ In the context of generalised poverty, irrespective of HIV/AIDS, almost all children are exposed to the same risks, though at varying levels. For example, the fact of being an orphan because of AIDS does not automatically make a child vulnerable if he is taken care of by the extended family where his needs can be met. On the other hand, a child who lost his parents due to another illness can be extremely vulnerable if he is taken care of by a poor family or if he lives in the street.
} 
work. Some associations were not motivated by the desire to help, but by the means allocated for work.

Two years later (2008), and barely 70,000 OVC (i.e. barely $25 \%$ of the target) having received support, the program stopped abruptly. Government authorities indicated that the project was suspended and not stopped. They were expecting it to start over before the end of the National Strategic Plan (NSP) to fight AIDS and STIs from 2011-2015 and funding from Round 10 of the Global Fund. This focus on subsidies from the Global Fund brings to light the extreme dependence of national policies on foreign funding. The suspension of NSP-OVC did not raise many reactions from care providers, possibly because UNICEF launched another program for OVC that drawn their attention.

Program 3: As part of its global campaign "Unite for children, Unite against AIDS," UNICEF identified four priorities (known as the 4P): Preventing mother-to-child transmission (PMTCT), Providing treatment for children, Preventing new infections among adolescents and youths, and Protecting and supporting OVC. These four priorities serve as a framework for the implementation of cooperation programs to fight against HIV and AIDS. Hinted in the bi-multi project, it is from 2008, with the signing of a cooperation program for 2008-2012 with the Cameroonian government that all $4 \mathrm{P}$ components were activated. Children, HIV and AIDS (CHA) is a UNICEF program, which serves as the last framework of action for OVC in Cameroon. Although it is a national program, it covers only few cities by region, and every activity is almost entirely funded by UNICEF. With the CHA program, for the first time, the management of pediatric HIV infection was considered as part of priority support programs for $\mathrm{OVC}^{2}$. Since 2000, as part of PMTCT programs, free access to treatment has been established for infected children born from HIV-positive mothers. Inspite of this, it was only in 2008 that its visibility was enhanced. Thus, despite the measures targeting children HIVinfected, few associations were aware of the HIV status of children in their care, let alone

\footnotetext{
2 The delay in paediatric care provision of the infection maybe justified by poor knowledge of the HIV infection in children, the existence of unqualified or poorly trained staff (and also unmotivated), early paediatric diagnosis challenges, insufficiency, and even lack of antiretroviral formulae adapted to children (Kojoué, 2013).
} 
that of their parent. This confirms the difficulty in operationalizing the concept of vulnerability in a context like Cameroon (country with limited resources).

Be it the bi-multi program or the NSP-OVC or CHA program, though all of them fall within HIV and AIDS policies, in practice, the HIV criterion was not really taken into account. Statistics on HIV-infected children or AIDS orphans are particularly imprecise. Given the context of fragility of most children, HIV infection (for parents or children) was not decisive as a selection criterion. It was quickly abandoned, considered as not contributing or contributing very little to the children's vulnerability rate (Femba, 2007; CNLS, 2008). These three programs show that the situation of children facing AIDS appears to be receiving particular attention in the global agenda of the fight against HIV/AIDS. In fact, what is noticed is the systematic presence of an international body behind each Cameroonian initiative (UNICEF, French Cooperation, Global Fund). Till date, there is no internal program led by the Cameroon government and not carried out by foreign actors. Can we then conclude to the marginality of this issue on the agenda of national stakeholders?

\section{A Plural Marginality Fuelled by the Weakness of local Stakeholders and the Political Context}

The conditions for the emergence and implementation of support programs for OVC in the fight against HIV/AIDS policies in Cameroon show that these programs are the product of institutional and international offers rather than as a result of formal requests. This confirms the idea of a "dissonant model" about Cameroonians AIDS public Policies (Eboko \& Kerouedan, 1999, Eboko, 2002). Particularly in Cameroon, public action precedes requests, or even exists without specific requests (although needs are real). Thus, it is with the three programs described above. These programs were designed and developed without the participation of local (and key) actors: associations, local political leaders and local NGOs. The latter were only involved at the end of the process, which is the execution of the program. Moreover, even after the arbitrary suspension of NSP-OVC in which they were officially engaged for five years, no specific reaction of protest or 
complaint was recorded. Support to OVC therefore appears as a priority at global level, but not at national level, and this may be due to the inertia of local agents.

\subsection{An assisting role and not an entrepreneur's role: About Cameroonian associations supporting OVC}

The setting up of local associations for collective action in Cameroon experienced fewer constraints than that related to freedom of the press, trade unions or political parties. With the liberalization of the political life in 1990 and in 1996, freedom of assembly took an unprecedented scale in the early 2000s; period during which the HIV epidemic became essential as a health issue, a challenge for development, international security, human rights and governance, and civil society highly participated in the fight against HIV/AIDS (Eboko \& Mandjem, 2010; Eboko et al., 2011; Kojoué, 2013). With increased means of fight granted to States by international institutions such as the Global Fund and PEPFAR $^{3}$, the Cameroonian associations witnessed a significant peak between 2002 and 2007. According to the National Committee on AIDS, there has been an increase of over $300 \%$ in five years (Kojoué 2013). Today, there are about 500 associations to fight against HIV/AIDS, only in the country's big city centers (GTC-CNLS. 2013).

Before the implementation of NSP-OVC in 2006, very few associations had included the component "Children and HIV/AIDS" in their programs. Open calls for tenders addressed by the Government and UNICEF led most entities to get involved. The NSPOVC, as well as the bi-multi or CHA program, could certainly rely on a dynamic civil society engaged in the fight against HIV and AIDS. Yet, this movement proved to be not only far away from concerns relating to children and AIDS, but also somehow not committed for the improvement of social determinants of HIV infection. In fact, it is widely accepted that social inequalities are the main cause of inequalities in health. The social environment where people are born, live, grow, work and age (the social determinants of health), refers to policy choices expressed in the form of social justice (Moleux et al., 2011; see also Chapter 4).

\footnotetext{
3 PEPFAR is the President's Emergency Plan for AIDS Relief. It is a U.S. Government initiative created in 2003.
} 
This calls for the following observation: the participatory nature of non-State organizations to national AIDS policies is a fact. This free participation in public action is not, however, accompanied by a advocacy action on the social determinants of health, nor on a real participation in the deliberations and final choices. Few associations involved in the fight against HIV/AIDS have the intellectual, social and economic capital to emerge as key actors in decision-making. Apart from some leading associations connected to international stakeholders, the institutionalization of OVC care providers remains low. Three main factors explain this low mobilization and the inability of local actors to stand as public policy entrepreneurs: an institutional weakness, an authoritarian political environment and the non-confrontational nature of the issue "Children and HIV/AIDS" (a non political issue).

Different actors with whom we conducted our survey in Cameroon show signs of extreme dependence vis-à-vis the State and vis-à-vis foreign partners. Reciprocity of interests between the State (who need the participation of civil society) and organizations fighting against HIV/AIDS (who need both resources and support from the State) vis-àvis international partners has strengthened relations of mutual dependence. Thus, when there are no funded projects underway, all association activities are paused, and their staff is inactive. There is clear absence of consistent advocacy and monitoring of the issues surrounding AIDS, particularly issues related to children less than 15 years.

In addition to this institutional weakness of Cameroonian associations, the private, social and non-controversial nature of the issue of children and HIV/AIDS may explain the OVC marginality. In many interviews, two arguments regularly came up: the social and private arguments, and the argument presenting HIV/AIDS as a health imperative. These two arguments are used to prevent any increase in generalization or politicization. Whether health professionals, NGOs or local associations, the biggest challenge in pediatric and social care for HIV-infected or affected children is primarily its 
environment, not the organizational and functional structure of national strategies ${ }^{4}$ : These speeches show how private the OVC issue is seen.

Taking care of children is very difficult and it mostly depends on the state of the family. Children are usually from poor families who sometimes do not have any information. It is a family issue. (An NGO leader)

The difficulty is that they are children and they are entirely dependent on parents, grandparents, guardians, and extended family, in short, adults. Most of them stay in their families and still HIVIAIDS is a taboo, nobody wants to talk about it in public. (A doctor)

The second argument that makes AIDS a health imperative suggests that it is a medical issue and decisions related are taken by professionals and are not to be argued. This means that all decisions regarding the fight against HIV/AIDS pertain to a class of experts that exclude laypersons. Local stakeholders in the fight against HIV/AIDS therefore exclude themselves from decisions spheres. Doing so, they are finally losing all ability to access the political arena, institutionalized space within which all negotiations and formal decisions are taken (Jobert \& Muller, 1987).

One factor, which probably explains why few actors dare to consider, is that taking care of OVC as a political issue, as well as other HIV/AIDS-related issues as PMTCT and access to care for men having sex with men (MSM) is probably a habitus, a long tradition of subordination to State power. Indeed, habitus lies in a gradual incorporation of social structures, patterns of thoughts and social practice adjusted to social positions. React by habitus is reacting spontaneously, without any calculation or express intention (Bourdieu 2000). In other words, the social, economic and political environment in which Cameroonian stakeholders operate pushes them to react spontaneously on the side of the HIV/AIDS victims, without seeking the culprits or criticizing the capabilities and ways in

\footnotetext{
4 This means that there is too little criticism concerning budgets (even if there is criticism concerning funds management), neither on the legitimacy of roles nor on the accountability of political authorities.
} 
which political authorities deal with the problem. This habitus of avoidance of politics and conflict maintain political neutrality, which not only strengthens the dominant position of the central government, but also marginalizes the cause for which they act collectively.

\subsection{A political environment not particularly favourable to public policies entrepreneurship}

It was with Paul Biya's accession to power in 1982 that the Cameroonian society witnessed some liberalization of the political space. President Biya is described as a liberal reformer in comparison to his predecessor Ahmadou Ahidjo, autocratic and backward looking (Bayart, 1985; Bigombé Logo \& Menthong, 1996; Sindjoun \& Courade, 1996). This opening-up paved way for political debates and led to the public emergence of strengthened non-State social dynamics, as is the case with the fight against HIV/AIDS. These dynamics are, however, closely related to State power that partially regulates their existence through its ability to control and sanction.

Despite the evolution of the Cameroonian legal framework regarding freedom of the press, freedom of assembly in associations and political parties and to hold meetings ${ }^{5}$, the political openness of Cameroonian public action remains controlled (Sindjoun, 1996; Pommerolle, 2008). The social and medical management of HIV infection in children demonstrates the constant centrality of the State and its institutions, as well as the weaknesses of decentralized actors. In fact, the concern for State control is permanent. This is the case with the National Committee to fight against HIV/AIDS, Malaria and Tuberculosis, which was established to coordinate the national response to HIV/AIDS (Country Coordinating Mechanism). These committees bring together all stakeholders involved in fighting AIDS: Government actors, financial partners, international actors, NGOs and local private associations or religious groups. Although this committee has many members who do not belong to State departments, its primary strategic positions

\footnotetext{
${ }^{5}$ Law of 19 December 1990 on the rights and freedoms of association, Freedom of the press and Freedom of assembly puts an end to close to 25 years of bans on freedom to publicly express political opinion contrary to that of the Unique party. Revised in 1996, this law extends even to collective and individual Cameroonian actors. This explains increase in the number of associations and NGOs will significantly increase and the dynamics of global mobilization against HIV/AIDS.
} 
are made by the Ministry of Public Health (the chair and the secretariat). This makes the government to be both judge and jury in the process of collective deliberations (Moulin. 2004).

Including non-State actors in the political fight against HIV/AIDS is a dual meaning strategy for political and administrative authorities. They acquire some legitimacy among patients living with HIV/AIDS and increase their credibility vis-à-vis their international partners (Kojoué 2013). The constant centrality of State power is also explained by Cameroon tensed economic environment since the succession of structural adjustment plans that deeply undermined its ability to deliver public services (health, education, agriculture, etc.) since the early 1990's. The scarcity of public resources and new governance requirements required from States with limited resources by the World Bank or the International Monetary Fund put them in competition with the leadership of new stakeholders who are increasingly numerous. In this context, civil society therefore has several reasons to be wary of financial sanctions (no more subsidies), civil sanctions (closure and seizure of premises) or criminal sanctions (fines, trials and convictions). Those who dare to publicly oppose State power run the risk of being severely punished. This is the case of the leader of Positive Generation a Non-governmental association who has been fighting against AIDS since the early 2000's. This leader admits to have been taken to court so many times for disturbing public order and threatening the security of the State because his organization, has repeatedly organized public demonstrations to advocate for the rights of PLWHIV. The relatively confined management of public action for OVC, therefore, reflects a quest for strong State control, a quest that never dropped with the democratization of health policies.

\section{Conclusion}

Non-state stakeholders can play an important role in the political dynamics to fight AIDS in Cameroon, but only if they become involved politically. However, most of them exclude themselves from the political debate, and thereby, give a free rein to government officials to set up priorities and lead their implementation. This is what is revealed by the analysis of OVC national policies in Cameroon. 
Several factors explain the non-politicization of civil society and AIDS-related actors. These factors are mostly related to the inability of civil society actors to disrupt social order and stand as entrepreneurs for public policies. This inability stems from internal and external constraints. Internally, the institutional and financial fragility makes any idea of autonomy and self-sufficiency to be delusive, but also creates distrust of established political order. At the external level, the authoritarian political context generates serious constraints, especially with regards to the will of some organizations and individual to participate out of formally instituted fields and standards. In addition, the risk of sanctions, together with institutional and organizational difficulties, significantly contributes to discard the issue of children and HIV/AIDS from national priorities, and even among priorities in fighting HIV/AIDS. 


\section{References}

Bayart, J.-F. (1985). L'Etat au Cameroun. Références, 2nd edition. Paris: Presses de Science Po.

Becker, H. (1985). Outsiders. Etudes de sociologie de la déviance, 1963rd edition. Paris: Métailié.

Bergeron, H., Castel, P., \& Nouguez, E. (2011). Un entrepreneur privé de politique publique: la lutte contre l'obésité, entre santé publique et intérêt privé, Revue Française de Science Politique, 61(2), 201-29.

Bigombé Logo, P., \& Menthong, H.-L. (1996). Crise de légitimité et évidence de la continuité politique, Politique Africaine, 62, 15-23.

Bourdieu, P. (2000) Esquisse d'une théorie de la pratique, Editions du Seuil, (Essais), Paris

Cobb, R., \& Elder, C. (1972). Participation in American politics: The dynamics of agenda building. Baltimore: John Hopkins University Press.

Eboko, F., \& Mandjem, Y. (2010). ONG et associations de lutte contre le sida au Cameroun. De la subordination vers l'émancipation. In Accès décentralisé au traitement du VIH/sida: évaluation de l'expérience camerounaise (269-285). Sciences sociales et sida, Paris: ANRS

Eboko, F., Bourdier, F., \&Broqua, C. (2011). Les Suds face au sida. Quand la société civile se mobilise. Objectifs Suds. Marseille: IRD Editions.

Eisenstadt, S.N. (1980). Cultural orientations, institutional entrepreneurs, and social change: Comparative analysis of tradition civilizations, American Journal of Sociology, 85(4), 840-69.

Femba, S.D. (2007). Analyse factorielle des correspondances multiples et classification automatique: appliction à la construction d'une grille d'éligibilité des OEV au Cameroun. Mémoire de Master. Yaoundé: Ecole Nationale Supérieure Polytechnique de Yaoundé.

Fligstein, N. (2001). Social skill and the theory of the field, Sociological theory, 19(2), $105-25$.

Garraud, P. (1990). Politiques nationales: élaboration de l'agenda, L'Année Sociologique, 40,17-41. 
Gillespie, S., Norman, A., \& Finlay, B. (2005). Child, vulnerability and HIV/AIDS in Subsaharan Africa: What we know and what can be done. [http://www.ids.ac.uk/files/dmfile/gillespieovcsynth.pdf, accessed $25^{\text {th }}$ October 2008

GTC-CNLS (2008) Rapport de progrès n 3, Yaoundé: GTC/CNLS

GTC-CNLS (2012). Estimation des ressources et des dépenses 2010 de lutte contre le VIH, le sida et les IST au Cameroun (REDES/NASA), Yaoundé: GTC/CNLS

GTC-CNLS (2013). Rapport annuel sur l'épidémie de sida 2013, Yaoundé: GTC/CNLS

Hassenteufel, P. (2010). Les processus de mise sur agenda: sélection et construction des problèmes publics, Informations Sociales, 1(157), 50-58.

Kingdon, J.W. (1984). Agendas, alternatives and public policies. Boston: Little Brown and Co.

Hunter, S., \& Williamson, J. (2000). Children on the brink: Executive summary. Updated estimates and recommendation for intervention, Washington DC: USAID

Kingdon, J.W. (1984). Agenda, Alternatives and Public Policies, Boston: Little Brown and $\mathrm{Co}$

Kojoué, L. (2013). Enfants et VIH/sida au Cameroun. Construction et implications de l'agenda politique. Thèse pour le doctorat en science politique. Bordeaux: Université Bordeaux IV/ED SP2/LAM, UMR 5115.

Lagroye, J. (2003a). La politisation. Paris: Belin.

Lagroye, J. (2003b). Les processus de politisation. In Lagroye, J La politisation (pp. 35972) Paris: Belin.

Lagroye, J. (2006). Sociologie politique. Paris: Presses de Science Po.

Moleux, M., Schaetzel, F., Scotton, C. (2011). Les inégalités sociales de santé: déterminants sociaux modèles d'action. http://www.ladocumentationfrancaise.fr/var/storage/rapportspublics/114000580/0000.pdf, http://www.ladocumentationfrancaise.fr/var/storage/rapportspublics/114000580/0000.pdf, accessed 6th june 2011

Moulin, B. (2004). Missions d'Etudes sur le Fonctionnement des Instances de Coordination Pays (CCM). Cameroun. p.55, Paris: CREDES

Muller, P. (2000). L'analyse cognitive des politiques publiques: vers une sociologie de l'action publique, Revue Française de Science Politique, 5092), 189-207. 
ONUSIDA (2013). Rapport mondial:Rapport ONUSIDA sur l'épidémie mondiale de sida 2013, Genève: ONUSIDA

Paxton, N. (2012). Political science(s) and HIV: A critical analysis, Contemporary Politics, 18(2), 141-55.

Piot, P (2010). L'épidémie du sida. Mondialisation des risques, transformations de la santé publique et développement, Leçon inaugurale, Chaire de recherché Savoirs contre pauvreté 2009-2010, Paris: Collège de France

Pommerolle, M.-E. (2008). La démobilisation collective au Cameroun: entre régime postautoritaire et militantisme extraverti, Critique Internationale, 3(40), 73-94.

Sindjoun, L. (1996). Le champ social camerounais: désordre inventif, mythes simplificateurs et stabilité hégémonique de l'Etat, Politique Africaine, 62, 57-67.

Sindjoun, L., \& Courade, G. (1996). Introduction au thème. Le Cameroun dans l'entredeux, Politique Africaine. 62, 3-14.

Singhal, A., Howard, S., \& Esack, F. (2003). The children of Africa confront AIDS: From vulnerability to possibility. Athens: Ohio University Press.

Skinner, D., Tsheko, N., Mtero-Munyati, S., Segwabe, M., \& Chibatamoto, P. (2004) Defining orphaned and vulnerable children, Social Aspects oh HIV/AIDS and Health Research Programme, Capetown: HSRC

Stone, D.A. (1989) Causal Stories and the Formation of Policy Agendas, Political Science Quaterly, 104(2), 281-300.

UNAIDS, UNICEF and USAID (2004). Children on the brink 2004. A joint report of new orphan estimates and a framework for action, New York: UNICEF

UNICEF (2006). Les générations orphelines et vulnérables d'Afrique. Les enfants affectés par le sida, New York: UNICEF

UNICEF (2013). Enfants et SIDA: sixième bilan de la situation 2013, New York: UNICEF

Williamson, J. (2008). Children made vulnerable by HIV and AIDS. A look back from where we've come, Washington D.C: USAID 